\title{
PROTRUDING TEETH THE FOCUS OF NOW
}

The British Orthodontic Society (BOS) launched this year's National Orthodontic Week (NOW) at the VetA Museum of Childhood in London.

The focus for NOW 2011, which ran from 22-28 February, was young people, highlighting in particular the problems of dealing with protruding teeth. To graphically illustrate the problems of protruding teeth the BOS commissioned the building of two life-size Lego heads showing mouths 'before' and 'after' orthodontic treatment. The heads were unveiled at the launch and on display throughout NOW.

In order to find out more about the public's attitudes towards protruding teeth, the BOS commissioned a YouGov survey. Two thousand and ninetytwo people aged over 16 took part; over $90 \%$ of them would want orthodontic treatment for themselves and/or their children if they had significantly protruding teeth and the same number felt it should be available on the NHS. The top four grounds for wanting treatment were to improve self-confidence; prevent teasing and bullying; prevent damage to the front teeth through trauma;

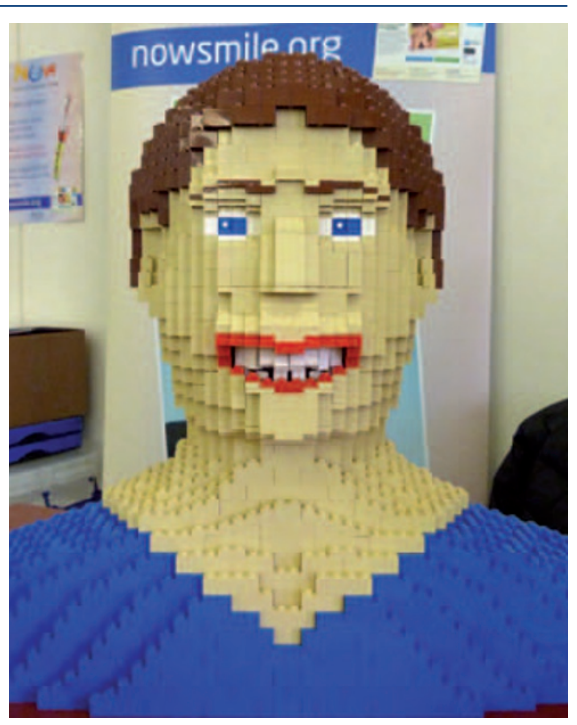

and to improve speech. Only half of the respondents thought that treatment was available under the NHS.

'Many [patients] think that orthodontic treatment [is] no longer available on the NHS,' commented Dr Nigel Harridine, BOS Chairman. 'In fact, many patients referred for treatment before 18 years of age with significant malocclusions fully qualify for treatment in the NHS. Older patients may still qualify for treatment if their condition is sufficiently severe.'

\section{MERGER WILL EXPAND DENTAL SERVICES}

Global alternative asset manager The Carlyle Group (Carlyle) has announced that it has signed a binding agreement to acquire Integrated Dental Holdings (IDH) from Bank of America Merrill Lynch Capital Partners (BAMLCP), and simultaneously merge it with Associated Dental Practices (ADP) in partnership with private equity firm Palamon Capital Partners (Palamon). Carlyle will hold a majority of the newly combined entity and Palamon will share joint governance. BAMLCP is fully exiting its stake in IDH. The proposed merger of IDH and ADP is subject to relevant regulatory approval.

IDH and ADP are two leading providers of dental care in the UK, primarily focusing on NHS dentistry, with close to 450 practices treating more than 3.5 million patients per year. Carlyle and Palamon will invest in the business to expand the number of practices, enhance the quality of patient care and grow NHS, private and specialist dental services. The investment will also facilitate the company's diversification into other primary care services and cosmetic treatments.

\section{FELLOWSHIP WILL BOOST RESEARCH AT BIRMINGHAM}

Owen Addison, clinical lecturer in restorative dentistry at the University of Birmingham, has been awarded a prestigious National Institute of Health Research (NIHR) Clinician Scientist fellowship.
The fellowship, which constitutes over $£ 900,000$ of research income to the School, will strengthen interdisciplinary research between biomaterials and tissue injury and repair. 